several possible explanations, including decreased renal excretion of $\mathrm{B}_{12}$, liberation of $\mathrm{B}_{12}$ from damaged kidney tissue, or a rise in the serum- $\mathrm{B}_{12}$-binding $\alpha$-globulin in parallel with the rise in the serum levels of other $\alpha$-globulins in renal disease. $A$ rise in the serum- $B_{12}$-binding $\alpha$-globulin has been demonstrated in uraemia (Herbert, 1967). This protein may be derived from breaking down tissues (white cells are normally an important source of the $\alpha$-globulin-binding protein) (Simons and Weber, 1966), but the exact source of the raised $B_{12}$-binding protein in uraemia remains uncertain. Dialysis had no immediate effect in vivo on the serum- $\mathrm{B}_{12}$ level comparable with its effect on the serum folate level. This is not surprising, since, unlike folate, $B_{12}$ is firmly bound to protein in serum and cannot be readily dialysed in vitro.

The presence of hypersegmented polymorphs in the blood films of uraemic patients with normal serum folate and $B_{12}$ levels supports the view that factors other than the folate or $\mathrm{B}_{12}$ deficiency produces this picture. Hampers et al. (1967) failed to detect a change in the white cell morphology when they gave folic acid in large doses to such patients. The explanation for the hypersegmented polymorphs in renal failure therefore remains obscure.

We wish to thank Dr. Oliver Wrong for permission to study patients under his care; the many house-physicians and members of the nursing staff who were involved in the clinical care of these patients ; and Mr. J. Morgan, who performed the microbiological assays. In addition, we are grateful to Miss R. Harrison and the dietetic department, who provided the special diets and estimated their protein and folate content.

\section{REFERENCES}

Anderson, B. B. (1964). Fournal of Clinical Pathology, 17, 14. Clinicopathological Conference (1966). American fournal of Medicine, 41, 593.

Dacie, J. V., and Lewis, S. M. (1963). Practical Haematology, 3rd ed. Churchill, London.

Goresky, C. A., Watanabe, H., anj Johns, D. G. (1963). fournal of Clinical Investigation, 42, 1841.

Hampers, C. L., Streiff, R., Nathan, D. G., Snyder, D., and Merrill, J. P. (1967). New England fournal of Medicine, 276, 551.

Herbert, V. (1967). Proceedings of the Asian Society of Hematology, New Delhi, p. 23.

Hoffbrand, A. V., Newcombe, B. F. A., and Mollin, D. L. (1966). fournal of Clinical Pathology, 19, 17.

Lasker, N., Harvey, A., and Baker, H. (1963). Transactions of the Ainerican Society for Artificial Internal Organs, 9, 51.

Mackenzie, J. C., Ford, J. E., Harding, N., Waters, A. H., and Cattell, W. R. (1969). Fifth Annual Meeting of European Dialysis and Transplant Association, Dublin. In press.

Matthews, D. M., and Beckett, A. G. (1962). Fournal of Clinical Patho$\log y, 15,456$

Mowbray, J. F., et al. (1965). British Medical fournal, 2, 1387.

Palmer, R. A., Newell, J. E., Gray, E. J., and Quinton, W. E. (1966). New England fournal of Medicine, 274, 248.

Register, U. D., and Sarett, H. P. (1951). Proceedings of the Society for Experimental Biology and Medicine, 77, 837.

Simons, K., and Weber, T. (1966). Biochimica et biophysica acta, 117, 201.

Waters, A. H., and Mollin, D. L. (1961). Fournal of Clinical Pathology, 14, 335 .

Whitehead, V. M., Comty, C. H., Posen, G. A., and Kaye, M. (1968). New England Fournal of Medicine, 279, 970.

\title{
Relapses and Remissions in Brain Stem Tumours
}

\author{
N. B. S. SARKARI,* M.D., M.R.C.P.GLASG., M.R.C.P.ED. ; EDWIN R. BICKERSTAFF, $\dagger$ M.D., F.R.C.P.
}

Summary : Three cases of brain stem astrocytoma and one of a para-stem vascular tumour are described, each showing a history of relapses and remissions. The diagnoses were confirmed by necropsy, and it is suggested that the relapsing course may have been due to oedema and necrosis in both the tumour and the surrounding brain tissue. Features indicating repeated recurrence of a lesion at the same site in the brain stem justify full neuroradiological investigation before a diagnosis such as multiple sclerosis can be accepted.

\section{Introduction}

Though brain stem gliomas are more common in children than in adults, all age groups may be affected. They usually present as a progressive disorder, consisting of oculomotor palsies, defects of conjugate ocular deviation, and other scattered cranial nerve palsies. Pyramidal or cerebellar defects may appear early or may be long delayed, but signs of raised intracranial pressure are uncommon until the later stages. It is not widely appreciated, however, that these tumours may show a relapsing

* Neurological Registrar.

† Consultant Neurologist. Midland Centre for Neurosurgery and Neurology, Smethwick, Warley,
Worcestershire. and remittent course, the remission sometimes being so complete and over such a long period that a diagnosis of multiple sclerosis may have been made, and regarded as correct until the final deterioration with headache, vomiting, coma, and respiratory failure brings the true diagnosis to light. Ford (1966) mentioned two children with brain stem glioma who had complete and spontaneous recovery and Sachs (1949) described a case in which the diplopia cleared up for several days before recurring. Apart from these reports, no other record of remission has been found in the literature.

The following four cases illustrate the course that some brain stem and para-brain-stem tumours take, and are recorded in the hope that they will emphasize the importance of keeping this diagnosis high among the differential possibilities when signs and symptoms continuously and repeatedly point to a lesion in this one part of the nervous system.

\section{Case 1}

A woman aged 21 gave a five-month history of right-sided dysaesthesia followed by diplopia and right internal strabismus. This recovered completely, but was followed by a left internal strabismus. She had had left-sided ataxia for eight weeks, left deafness and tinnitus for three weeks, early morning headache with occasional vomiting for four weeks, and amenorrhoea for three months. 
Examination showed a left seventh-nerve palsy, nystagmus to the right, slight left-sided deafness, and a left-sided cerebellar ataxia. All tendon reflexes were exaggerated, right more than left, the abdominal reflexes were absent, and the right plantar response was equivocal.

Investigations.-Blood count, blood serology, cerebrospinal fluid (C.S.F.) examination, electroencephalography (E.E.G.), and $x$-ray examination of the chest and skull showed nothing abnormal. Erythrocyte sedimentation rate (E.S.R.) was $25 \mathrm{~mm}$. Audiogram showed slight nerve deafness. Caloric tests were normal.

During investigation all symptoms and signs completely cleared but four months later she developed headache and vomiting and became unconscious, with marked neck stiffness. Examination showed stupor, anarthria, neck stiffness, impaired conjugate movement to the left with left sixth-nerve palsy, left lower motor neurone facial paralysis, and deafness in the left ear. Pain sensation was impaired on the left side of the face and the right side of the body. There was generalized hyperreflexia and both plantars were extensor.

Reinvestigation showed a polymorphonuclear leucocytosis, E.S.R. $100 \mathrm{~mm}$., and a xanthochromic C.S.F. at $220 \mathrm{~mm}$. pressure containing $490 \mathrm{mg}$. of protein per $100 \mathrm{ml}$. Air ventriculography showed hydrocephalus due to obstruction in the fourth ventricle.

She died five days later, and necropsy showed the pons and medulla almost completely replaced by an anaplastic astrocytoma which surrounded the seventh and eighth nerves in which were grooves made by the vertebral and anterior inferior cerebellar arteries.

\section{Case 2}

This patient was a man aged 34. At the age of 18 his head flexed to the right for six weeks and recovered. Nine months before admission the left hand became weak for three hours and recovered. Six months later the left arm and leg developed progressive weakness.

Examination showed dysarthria, horizontal nystagmus, right-sided palatal weakness, and wasting with fasciculation of the right side of the tongue. The left arm and leg were spastic, with exaggerated reflexes and extensor plantar.

Investigations-Blood count, E.S.R., blood and C.S.F. serology, and C.S.F. analysis were normal. C.S.F. pressure was $210 \mathrm{~mm}$. E.E.G., $x$-ray examination of chest and skull, and vertebral arteriogram showed nothing abnormal. Air encephalography showed backward displacement of the fourth ventricle.

Ten hours afte: vertebral angiogram he developed respiratory distress, became comatose, and died. Necropsy showed the medulla enlarged and distorted by a well-differentiated astrocytoma which almost completely surrounded the right vertebral artery.

\section{Case 3}

A girl aged $4 \frac{1}{2}$ years developed headache, vomiting, and drowsiness after a minor head injury, and she walked with a broad-based ataxic gait and had a right hemiparesis. All the signs and symptoms cleared up except for a slight limp. Twelve months later she developed progressive weakness of the right side, unsteadiness, headache, and vomiting. Her left upper eyelid gradually drooped.

Examination showed bilateral papilloedema, partial left third- and mild sixth-nerve palsy, right hemiparesis, and cerebellar ataxia on the left. Tendon reflexes in the lower limbs were exaggerated and the right plantar was extensor.

Investigations.-Blood count, E.S.R., ventricular C.S.F. analysis, blood, and C.S.F. serology were normal. E.E.G. showed bilateral slow waves. $X$-ray examination of chest showed nothing abnormal. $\boldsymbol{X}$-ray examination of skull and right carotid angiogram showed features of hydrocephalus. Air ventriculogram revealed enlarged lateral ventricles due to an obstruction by a space-occupying lesion of the fourth ventricle which had displaced the lower end of the third and fourth ventricles backwards and to the right.

Her condition gradually deteriorated and she died eight weeks later. Necropsy showed enlarged lateral ventricles. The left side of the fourth ventricle and the posterior end of the third ventricle were replaced by cystic astrocytoma which extended up to the optic chiasma and anterior internal capsule.

\section{Case 4}

A girl aged 13 gave a history of left occipital headache for four to five years. Ten days before admission she develcped severe headache followed by vomiting, diplopia, and unsteadiness, with falls to the left.

Examination showed horizontal nystagmus to the right, lower motor neurone weakness of the left face, and left-sided cerebellar ataxia with exaggerated left-sided tendon reflexes. Blood pressure was $130 / 100 \mathrm{ml}$.

Investigations.-Blood count, E.S.R., and blood and C.S.F. serology were normal. $X$-ray examination of the chest and skull showed nothing abnormal. The C.S.F. showed lymphocytosis with total cells of 23 and $27 / \mathrm{cu}$. $\mathrm{mm}$. at two subsequent examinations and protein of 65 and $52 \mathrm{mg} . / 100 \mathrm{ml}$. E.E.G. showed slow waves on the right. Air and iophendylate (Myodil) ventriculography revealed dilatation of the lateral and third ventricles.

She gradually improved, and ataxia, double vision, and headache disappeared. She was seen on five occasions at intervals of six months ; each and every time the only detectable sign was nystagmus. Four months after her last examination she was readmitted with severe headache, vomiting, pain and stiffress of the neck, and double vision.

Examination revealed marked spinal rigidity, bilateral papilloedema, motor and sensory impairment of the left fifth nerve, bilateral sixth-nerve weakness, lower motor neurone left facial weakness, complete deafness in the left ear, horizontal nystagmus, and left-sided ataxia.

Investigations.-Blood count showed polymorphonuclear leucocytosis, E.S.R. $55 \mathrm{~mm}$., C.S.F. xanthochromic at pressure of $200 \mathrm{~mm}$., red cells 45,000/cu. mm., white cells 19/cu. mm., and protein of $170 \mathrm{mg} . / 100 \mathrm{ml}$.

$X$-ray examination of skull and chest, vertebral angiogram, and iodophendylate ventriculogram showed nothing abnormal.

She gradually developed ophthalmoplegia, progressive bulbar palsy, became areflexic, and died 18 days later. Necropsy showed intense orange brown staining of leptomeninges of the occipital pole and over a firm lobular ovoid tumour of the left cerebellopontine angle. This was full of laminated thrombus without clear evidence of vessel wall. It had compressed the medulla medially, displaced and compressed the sixth, seventh, eighth, ninth, tenth, and twelfth cranial nerves, and a small area of cerebellar cortex was necrosed. There were changes of bronchopneumonia in the lungs. The right kidney had a solitary cyst and foetal lobulation. The uterus was infantile.

\section{Discussion}

If a young patient shows the symptoms and signs of a brain stem lesion which, having been present for some days or weeks, remit completely, multiple sclerosis becomes the most likely diagnosis. It is, however, a diagnosis which should always be made with caution, for there is a very real danger that if this "label" is attached to a patient it will remain, and may well be used to explain any and every subsequent clinical manifestation even if the new features are unusual in demyelinative disease. Particular care should therefore be taken if the signs of brain stem disturbance are accompanied by significant headache and vomiting, and any alteration of conscious level should be viewed with added caution. Again the value of the wellestablished term "disseminated" sclerosis was that it emphasized the need for the lesions to be disseminated in the nervous system, preferably in both time and place, and when signs repeatedly point to a lesion in the same area such cases warrant full investigation.

The finding of a brain stem glioma may worsen the prognosis, but the possibility arises that an extrinsic tumour impinging on the brain stem might be found which might be capable of surgical eradication. In investigating this type of case the value of both introducing air or iophendylate into the ventricular system and of carrying out vertebral arteriography is very considerable, for, whereas both intrinsic tumours of the stem and those lying anterior to it displace the aqueduct and the fourth ventricle backwards, intrinsic tumours press the basilar artery 
forwards on to the clivus, while lesions such as the clivus meningioma will displace it away from the skull base.

The cases described in this paper illustrate how complete the remission may be in both gliomas and vascular tumours. The mechanism of the relapses and remissions is uncertain, but presumably is similar to that seen in tumours elsewhere in the nervous system-necrosis and oedema in the tumour itself, haemorrhage into or around it, and necrosis and oedema in the surrounding brain tissue due to the involvement of the small blood-vessels. Such oedema might be influenced by corticotrophin and so give an apparent therapeutic response and reinforce the diagnosis of demyelinative disease. Certainly in Cases 1 and 2 there was involvement of the vertebral artery and Case 3 showed cystic degeneration. Hormonal influences may also play a part. Bickerstaff et al. (1958) showed how clearly the behaviour of some parasellar meningiomas can be related to pregnancy and menstruation, and a similar mechanism may be felt at any site where only a slight enlarge- ment of the tumour is required to produce a dramatic increase in symptoms.

It is the awareness of the possibility that such remissions may occur that is important, and the realization that though, like lightning, multiple sclerosis may strike more than once in exactly the same place such an event should raise great doubts about the diagnosis and stimulate full neuroradiological investigation.

We thank Dr. J. McDonald Holmes for permission to report his case and Miss S. Ray for her help at various stages.

\section{REFERENCES}

Bickerstaff, E. R., Small, J. M., and Guest, I. A. (1958). Fournal of Neurology, Neurosurgery, and Psychiatry, $21,89$.

Ford, F. R. (1966). Diseases of Nervous System in Infancy, Childhood, and Adolescence, 5 th ed. Thomas, Springfield, Illinois.

Sachs, E. (1949). Diagnosis and Treatment of Brain Tumours and Care of the Neurosurgical Patient, 2nd ed. Mosby, St. Louis.

\title{
Role of Candida albicans Infection in Napkin Rashes
}

\author{
P. N. DIXON,* M.B., D.P.H. ; R. P. WARIN, $\dagger$ M.D., F.R.C.P.; MARY P. ENGLISH, $\ddagger$ M.SC. \\ With the Technical Assistance of LiNDA GRENFEll
}

British Medical fournal, 1969, 2, 23-27

\begin{abstract}
Cummary: Skin scrapings, mouth swabs, and faecal $S$ specimens from children with eruptions in the napkin area and from a series of normal infants were examined for the presence of Candida albicans.

This was found in $41 \%$ of all napkin eruptions but in only one of the 68 normal infants. While C. albicans is a common secondary invader of all types of napkin eruption, primary candida infection of the skin in the napkin area is probably uncommon.

No evidence was found that generalized psoriasiform or eczematous eruptions occurring in association with napkin rashes are due $t$ an allergic response to the fungus. C. albicans is more likely to be present in a napkin rash if the organism has been found in the alimentary tract.
\end{abstract}

\section{Introduction}

Four main types of napkin eruption are usually described, and include the common napkin rash due mainly to irritation by ammonia, seborrhoeic (intertriginous) eczema, a psoriasislike eruption (napkin psoriasis), and an eruption reported as a primary Candida albicans infection. C. albicans is well recognized as an opportunist organism growing where general and local conditions are favourable, and among these conditions moisture and a pre-existing skin disorder are important. C. albicans has been recovered from the alimentary tract of up to $31 \%$ of infants under the age of 9 months (Beare, Cheeseman, and Mackenzie, 1968), and it is therefore not surprising that the organism has been isolated from napkin rashes of all types. When so discovered $C$. albicans may well be accepted as having a primary role in the napkin eruption, and psoriasiform or

* Assistant Medical Officer, City and County of Bristol.

† Dermatologist, United Bristol Hospitals.

‡ Mycologist, United Bristol Hospitals. eczematous lesions which may develop in other sites of the body have often been considered to be either a spread of the infection or an allergic response to the fungus.

In the present investigation we compare the prevalence of C. albicans infection of the skin and alimentary tract in children with different patterns of napkin eruption and in a series of normal controls. Our purpose was to determine, firstly, whether infections of the skin in the napkin area by C. albicans were more likely to be primary or secondary in origin, and, secondly, whether there is any evidence for a causal relationship between $C$. albicans infection and generalized psoriasiform or eczematous eruptions.

\section{Material}

The cases included in the investigation were either referred by their doctors to the dermatological outpatient department of one of the Bristol hospitals or were attending certain of the local authority's child welfare clinics. Very little further selection was made. All children with a napkin eruption who attended the dermatological clinic at the Royal Hospital for Sick Children during the period of the investigation were included. Occasionally in child welfare clinics time did not permit the inclusion of some children with a napkin rash, but this happened only rarely.

Group I. Napkin Psoriasis.-Of the 27 cases in this group 24 were referred to the Royal Hospital for Sick Children between April 1967 and June 1968 and three were seen at other hospitals. The eruption usually starts in the napkin area, often mainly on the napkin contact sites, and consists of patches of brown-red skin with some scale and well-marginated figurate edges often enclosing areas of normal skin. Lesions of up to $10 \mathrm{~cm}$. in diameter or larger, all with well-defined edges, then develop on the trunk and limbs and usually the scalp, 